\title{
Oscar night, 2054
}

\section{A collection of heavenly bodies.}

\section{Syne Mitchell}

Total Health ${ }^{\mathrm{TM}}$ : You, Only Better! presents a night at the Oscars. Beatrice Barnard and George Ford help you sort fashion triumph from catwalk disaster. Remember, with Total Health ${ }^{\mathrm{TM}}$, it's still you - only better!

BB: First on the carpet tonight is pop singer Alexa DuBois, stunning in an offthe-shoulder Giovanni dress whose mocha silk highlights the leopard pattern of her skin. Her body modifications were done by the renowned designer Leonardo Fontesca, so it's no wonder that the work is subtle and flattering.

GF: At her side, sporting a crest of blueblack feathers, is Howe Yorkins, the tennis star. Alexa may look like the cat who swallowed the canary, but he belongs back on the poultry pharm.

Next up is Neo Washington, up for best actor for his part in the ground-breaking third remake of Gone with the Wind. Off the set, he flaunts his political vegetarian stance with a photosynthesizing teal complexion. The Greens behind the velvet ropes have gone insane, cheering and holding up 'Meat Kills' signs. Only Neo could mix ethics and fashion and make it work. We love you, Neo!

BB: Following Neo is the quartet of AI specialists whose virtual personality, Babylon Brown, is nominated for best actress for her role as Hillary Clinton in the historical drama You Go, Girl. They've made an attempt at cohesion, if not style, by wearing identical white lab coats over jeans and black T-shirts, bought online from AmazonMart, no doubt. Their pedestrian modifications are typical gamer-geek fare: enlarged eyes, polydactyl digits, and a revved-up nervous system that makes them twitch like crickets on a griddle.

GF: Back to the lab, boys!

On the carpet now is Medusa Addams, the character actress we all love to hate. Her puff-adder up-do is a-glitter with diamonds as each of her 24 snakes is wearing a customfit tiara. She completes the look with a skintight snakeskin sheath — oh wait! That is her skin. Cheeky, Medusa, very cheeky.

BB: Here's fitness guru Radha Guriampadaya, wearing an uninspired electric-blue bikini over buzz-cut fuchsia fur. Hell-o! Anime is so $\mathrm{O}-\mathrm{V}-\mathrm{E}-\mathrm{R}$ !

GF: Her companion, Susanna Belle, is positively fey in a bell-shaped diaphanous silk shift, complemented by feathery antennae and glistening dragonfly wings.

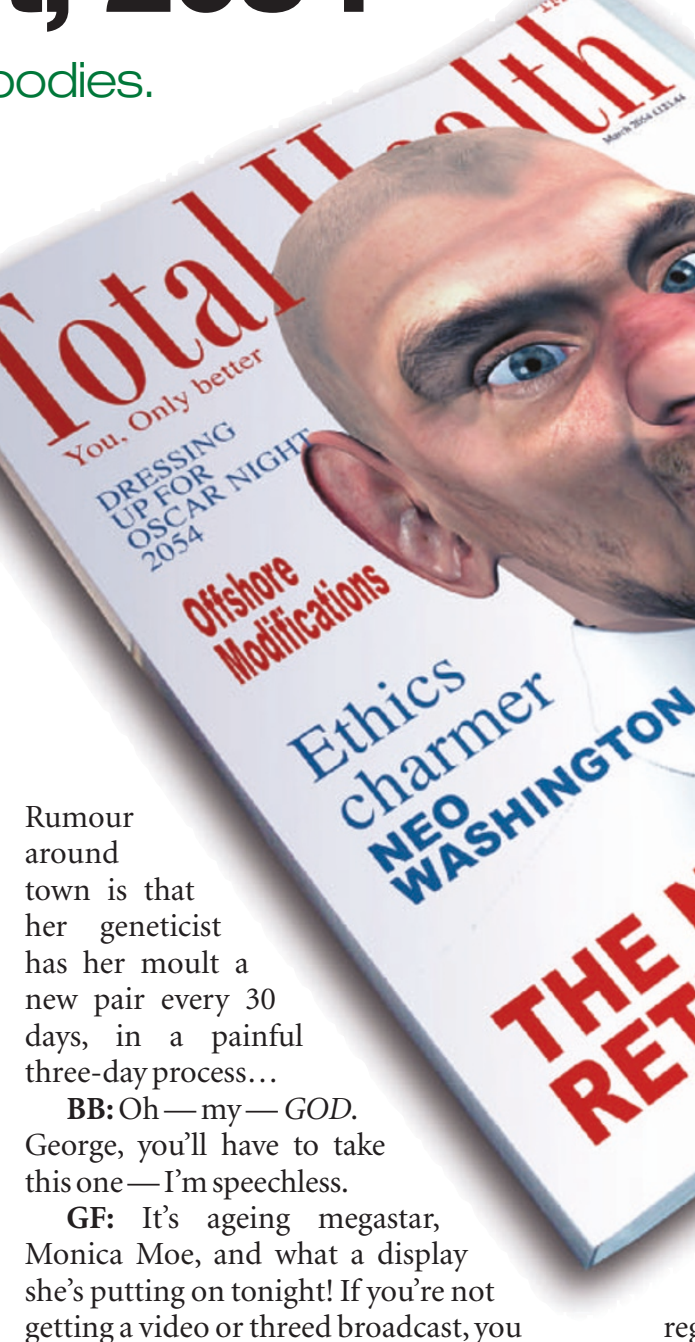
must check out the Internet archives. Sporting what can only be offshore modifications, she's got cleavage down to her hips, and I mean that literally. In white pleated chiffon, she looks like a cross between Marilyn Monroe and Artemis Ephesia. I count four, six, no — eight pairs of breasts. Well, slap my cheeks and put me on the cover of 'Trying Too Hard' monthly.

BB: Just stepping out of the limo is teen superstar Alessandro Goldstein. The crowd's gone wild. He - yes, it's true - the child prodigy singer/actor/supermodel is classic and divine in black leather pants and jacket, gold-net undershirt and sporting an amazing retro-humanist look with no obvious modifications. Could that flawless body be natural? Only his geneticist knows for sure.

GF: At Alessandro's side is his child bride and the youngest Nobel laureate, Dame Bekka Davis Llewellyn, who won last year's highest scientific honours for her work on inserting and upgrading artificial human chromosomes. She positively glows in a cowlneck gold-lamé top over an A-line floorlength velvet skirt. Very Audrey Hepburn. Like her husband, she displays no obvious enhancements ... although nasty rumours regrettable that such extremists have found a place in the public eye. The effect they are having on today's youth is deplorable. Anywhere you look you can see young people flaunting genetic flaws: buck teeth on the Transatlantic Tunnel, stringy lifeless hair on the Prada Channel, even love handles at the Milan Show for fashion's sake!

GF: Don't worry Bea, retro-humanism is a passing fad. Body modifications will always be with us. Engineers will always have work. Gene-Es don't go back in bottles.

Total Health ${ }^{\mathrm{TM}}$ reminds its subscribers that due to a shortage in recombinant DNA reagents, this year's chromosomal updates are only available to those subscribers who are critically ill, under 24 months in age, or whose updates are more than two years out of date.

Syne Mitchell is an award-winning author of several science-fiction novels, including biotechnology thriller The Changeling Plague and near-future space adventure End in Fire. She lives in the foothills east of Seattle with her husband, SF-writer Eric S. Nylund, and their toddler son Kai. She is resplendent in authorial post-fashion irony: denim overalls over a hemp shirt and antique Birkenstocks. No body modifications are visible. 